\title{
The relationship between daily spiritual experience and happiness of elderly members of Isfahan retirement center in 2014
}

\author{
Sharifi $\mathrm{S}^{1}$, abbasi $\mathrm{S}^{2^{*}}$
}

\begin{abstract}
Introduction and purpose: Retirement and old age are often interrelated phenomena that happiness and life's satisfaction of elderly decrease Because of social changes such as the loss of job and friends. Considering the role of spirituality in better cognition of life's meaning and adapting to elderly age changes, the aim of this study was to determine the relationship between daily spiritual experience and happiness and life's satisfaction of the retried elderly members of Isfahan retirement center in 2014

Materials and Method: This descriptive-analytic study was done among 190 retired elderly who were referred to Isfahan retirement center and were selected by simple sampling. The information collected via demographic variables, oxford happiness scale and daily spiritual experiences scale. Data analysis by software SPSS 21 and Descriptive Statistical tests, Pearson correlation coefficient, ttest and ANOVA.
\end{abstract}

Findings: In this study the mean score of life satisfaction of elderly was lower than average (34.56 \pm $11.45)$, the mean score of their daily spiritual experiences was in appropriate level (16.9 \pm 73.11$)$ and life's satisfaction was in average (17/21 $\pm 5 / 91)$. In addition results showed significant and positive correlations between daily spiritual experiences and happiness and life's satisfactions of elderly $(\mathrm{p}</ 05)$.

Conclusion: according to the results, when retired elderly have more daily spiritual experiences, they will be happier and they will have more life satisfaction. So, getting comprehensive view to the elderly spiritual needs in health educating programs, which will induce more appropriate care, seems necessary.

Key words: older adult, Daily Spiritual experiences, Happiness, life satisfaction

Copyright () 2018 Quarterly Journal of Geriatric Nursing.This is an open-access article distributed under the terms of the Creative Commons Attribution international 4.0 International License(http://creativecommons.org/licenses/by /4.0/) which permits copy and redistribute the material, in any medium or format, provided the original work is properly cited.

1 - MSc of geriatric nursing, School of Nursing and Midwifery, Isfahan University of Medical Sciences, Isfahan, Iran

2- MSc of psychiatric nursing, School of Nursing and Midwifery, Isfahan University of Medical Sciences, Isfahan, Iran (Corresponding Author):E-mail: samiraabbasi6853@gmail.com 


\section{ارتباط تجربيات معنوى روزانه با شادكامى و رضايت از زندَى سالمندان \\ شمر اصفهان در سال سوسا}

سميه شريفى'، سميرا عباسى "r.

تاريخ دريافت مقاله: / • / / هوسا

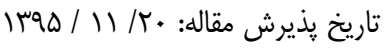

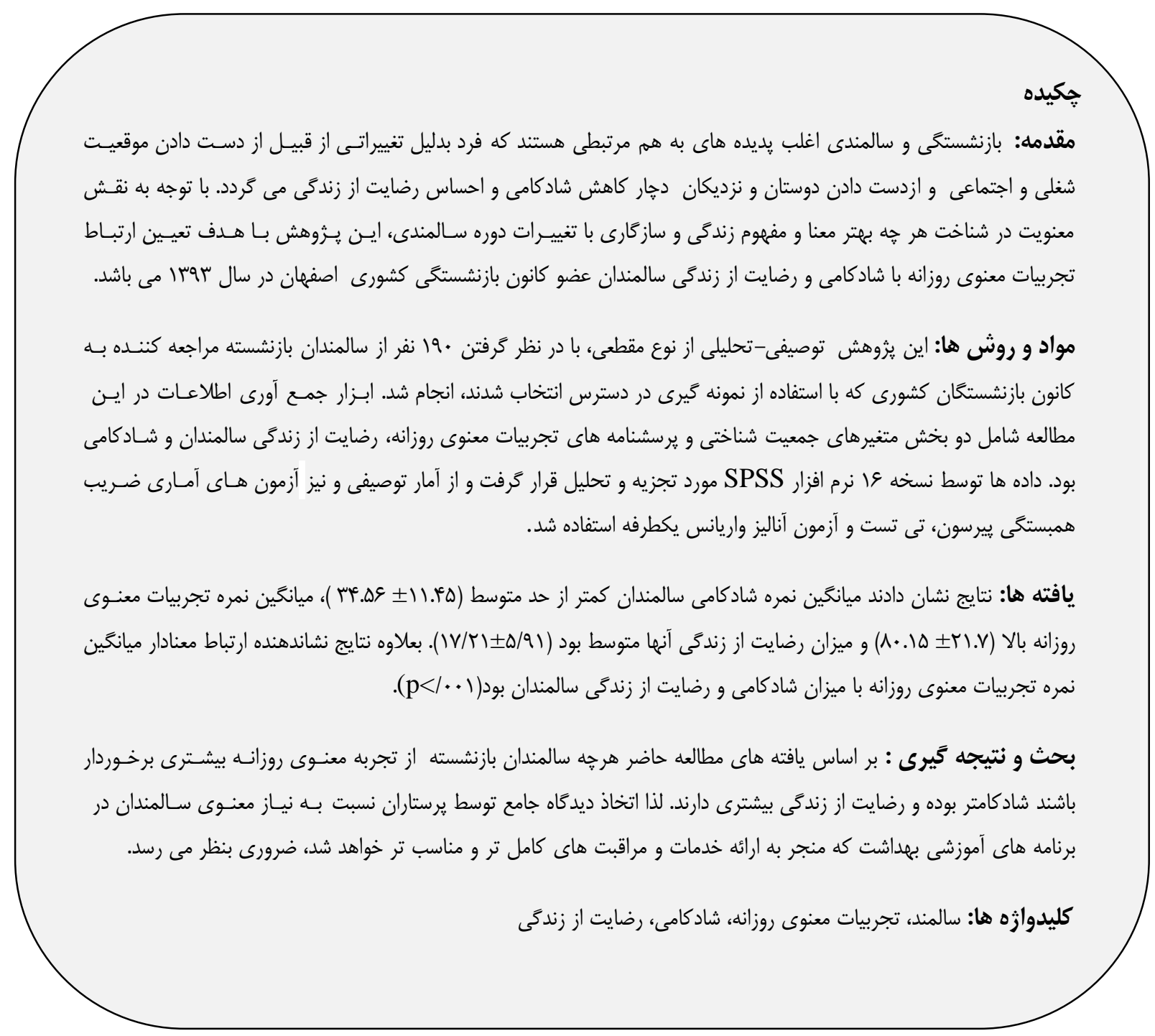

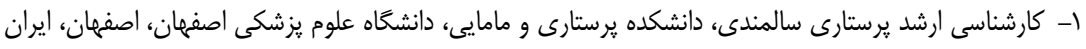

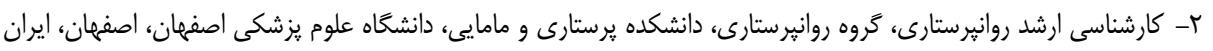
(نويسنده مسؤول). يست الكترونيكى: samiraabbasi6853@gmail.com 
هيجانات مثبت، راضى بودن از زندگى خود و فقدان افسـردگى، اضطراب و سـاير هيجانـات منفى مـى دانـد (و). درمجمـوع، يثوهش ها و تحقيقات مربوط به شادى، نشان دهنده آن اسـت كه افراد شاد از نظر ساختار فكرى، قضاوت و انخيـزش بـاديخر افراد تفاوت داشته، از بازدهى فردى، خانوادگى، شغلى، تحصـيلى و اجتماعى بالاترى برخوردار بـوده و از رضـايت زنـدگى بهتــى برخوردارند (V). رضايت از زندكى به عنوان نشـانه اي بـارز از سازگًارى بر ابعاد مختلـف زنـدگى سـالمندان اسـت و در واقـع بازتاب توازن ميان آرزوهاى شخص و وضعيت كنـونى او بـودهو نشانكَر آن است كه فرد هُخونه زندگى خـود را در ارزيـابى مـى كند. در حقيقت، رضايت از زندكَى به اين معناسـت كـه تـا هـهـ اندازه نيازهاى اساسى بر آورده شده اند (^) رضايت از زنسدكى از مهمترين شاخص هاى وضعيت سلامت روان در سـالمندان مسى باشد كه در سالمندان بازنشسته بدليل تجربـه انـواع مشـكلات و فقدان ها كاهش مى يابد (9) .رضايت اززندگى و ميزان شادكامى در دوران سالمندى تحت تاثير مرور زندگى گذشـــه فـرد اسـت و

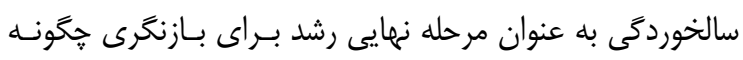
كذراندن زندگى كذشته است. ادامه رشد فرد در ايسن دوره وقتى ميسر است كه بتواند با واقع بينـى و انعطـاف يـذيرى خـود را بــاـ فقدان ها و تغييرات سازگًار سازد و اين سالهاى عمـر خـود را بـاـا احساس ارزشمندى و موثر بودن بخذراند و زندگى خود را معنـادار ديده و احساس رضايت كند (•). در همين ارتباط به نظر مسى

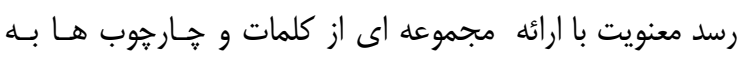
افراد كمك نمايد تا معنا ومفهوم زندگى خود را بهتر درى كنــــ (1) . در واقع معنويت، بعدى ازابعاد وجودى انسـان اسـت كـه ارتباط و يكيارجگگى او را با عالم هستى نشان مى دهـد. ارتبـاط ويكيارجگىى به انسان اميد و معنا مى دهد و او را از محدوده ى
تركيب جمعيت جهان در حال تغيير بوده و ييشرفت هاى دانش يزشكى و فن آورى هاى شَّفت انگَيز جهان امروز، اين رونـــــا سرعت بخشيده و به تبع آن افزايش اميد به زندكَى بــه عنـوان يكى از ييامدهاى ايـن ييشـرفت و توسـعه سـريع، تعـداد افـراد سـالمند را افـزايش داده اسـت((). در حـال حاضـر سـالمندان (جمعيت •و سال و بالاتر)، بيشترين نـرخ رشـد جمعيتـى را در دنيا در مقايسه با ساير گروه ها دارند. انتظـار مسى رود براسـاس روند حاضر، جمعيت سالمندان دنيا تا سـال •ه+r بـه سـه برابـر سال • ... افزايش يابد و به دو ميليارد سالمند برسد(ץ). كشـور ما نيز به عنوان يكى از كشورهاى در حال توسعه، ازاين قضـيه مستثنى نيست؛ براساس سرشمارى سال • وسابيش از \& ميليون (r^٪) جمعيت ايران را افراد •و ساله وبالاتر تشكيل مى دهنـــ و اخر اين سير ادامه ييدا كند، از اين پِ در ايران شاهد جمعيتى خواهيم بود كه از آن به عنوان جمعيت سالمند ياد مى شـود(ب). دوره پايانى ميانسالى و آغـاز دوره سـالمندى، بــراى بسـيارى از سالمندان همراه با تغيير و تحولاتى است كه در ابعاد روانسى و جسمى آنها اتفاق مى افتد. شواهد موجود حاكى از آن است كـهـ در دوره سالمندى، ميزان فشار تجربه شده توسط فـرد و تبعـات جسمى و روانى آن به صورت بارز و خشـمخيرى بـيش از دوره قبل از آن است (أ) و ممكـن اسـت فـرد بــليل از دسـت دادن موقعيت شغلى و اجتمـاعى و ازدسـت دادن دوسـتان و نزديكـان دجار گَوشه نشينى اجتماعى گردد كه با ايجاد اين تغييرات كاهش شادكامى امرى غير قابل اجتناب اسـت (ه). در مـورد شـادكامى تعاريف متعددى شده است كه بر اساس يكى از جامع ترين آنهـا شادكامى به درجه يا ميزانى اطلاق مى گردد كه شخص درباره مطلوبيت كل كيفيت زندگى خود قضاوت مى كند. آركايـل نيـز شادمانى را عبارت از بودن در حالت خوشحالى و سرور و ديخـر 
شادكامى سالمندان بازنشسته بــليل تجربـه انـواع فقــدان هـا و مشكلات يايين است لذا با توجه به بافت فرهنگى مذهبى جامعه ما سالمندان بازنشسته با افزايش تجارب معنـوى خـود در طـول روز بتوانند شادتر زندگى كنند لذا هـدف از انجـام ايـن يـرَوهش تعيين ارتباط تجربيات معنوى روزانـهـ بــا شـادكامى در سـالمندان بازنشسته عضو كانون بازنشسـتخى كشـورى اصـفهان در سـال

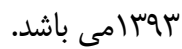

( مندرج در يرونده) بود. لازم به ذكـر اسـت كـه قبـل از انجـام يثروشش، در مورد اهداف يُوهش به افراد مورد مطالعـه توضـيح داده شد و علاقمندى آن ها جهت شركت در يزوهش جلب شد و بعد از امضاى فرم رضايت نامـه كتبـى شـركت در يـروهش، يرسشنامه ها در يك مرحله به صورت خودَّزارش دهى تكميـل كَديد. ابزار جمع آورى اطلاعات در اين يُوهش شامل دو بخش بود. بخش اول شامل اطلاعات دموگر افيـك نمونسه هـاى مـورد يثزوهش ( سن، جـنس، ميـزان تحصـيلات، وضـعيت تأهـل) و بخش دوم يرسشنامه سه قسـمتى تجربيـات معنـوى روزانـه' ، شادكامى آكسفوردَّ و بود. تجربيات معنوى روزانه سالمندان با يرسش نامه تجارب معنوى روزانه آندروود وترسى بّ سنجيده شد كه ايـن يرسشـنامه توسـط آندروود وترسـى در سـال r +.r طراحسى شـده اسـت(ها). ايـن يرسشنامه عاسوالى، يكى ابزار خند بعـدى از معنويـت اسـت كـــ درى افراد را از يكى نيروى برتر (الله، خــدا) درزنــدىى روزمــه و تعامل فرد با اين وجـود مـافوق جهـان مـادى مسى سـنجد و بـــ تجارب معنوى افرادو نه عقايد و رفتارهـاى خـاص مـذهبى ايـن
زمان و مكان و علايق مادى فراتـر مـى بـرد (TI). در همـين ارتباط نتايج مطالعه ادلر و فاگلى (ه+ +r) نشان داد كه رضايت از زندگىى، از ميزان خودآكاهى، خوش بينى و معنويت گرايسى فـرد متأثر است؛ هرجه افراد خودآكًاه تر و خوشـبين تـر و از معنويــت كرايى بالاترى برخــوردار باشـند، بـهـ همـان ميـزان از رضـايت بالاترى برخوردارند(سا). يعقوبى، محققى و منظمى تبـار(Y (Iس)) نيز نشان داد كه بهزيستى معنوى و اميـدوارى، از عوامـل مهـم رضايت از زندگى در سالمندان هستند(أ(1). بـدليل اينكـه ميـزان

\section{مواد و روش ها - - ما}

اين يزوهش يكى مطالعـه توصـيفى - تحليلـى از نـوع مقطعى بود.جامعه يُزوهش در اين مطالعه را كليه افراد سالمند •ع سـال و بالاتر عضو كانون بازنشستخان اصفهان تشكيل دادند. يزوهشـحر קِ از اخذ مجوز از دانشكده يرستارى و مامايى دانشـعاه علـوم يزشكى اصفهان و كسب اجازه از مسئولين كانون، اقدام به نمونه گيرى نمود. در اين مطالعه نمونه گيرى به مدت دو ماه با استفاده از جدول اعداد تصادفى و از ميان يرونده هاى مراجعين به كانون

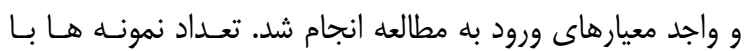
استفاده از فرمول آمارى N=((z1+z2) $\left.{ }^{2}\left(1-r^{2}\right) \div r^{2}\right)+2$ و

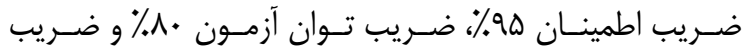
همبستخى حداقل r/.، حجم نمونه حداقل •19 نفر بدست امـد. معيار ورود به مطالعه شامل سن •ع سال و بالاتر، توانايى پاسخ حــويى بــه سـؤالات قرسشـنامه، تـوان برقـرارى ارتبـاط و عــدم معلوليت هاى شناخته شده ذهنى و جسمى و روانى ناتوان كننده
1 -Daily Spiritual Experiences Scale

2 -Oxford Happiness Inventory

3 -Underwood\& Teresi 
سالمندان تهرانى اجرا نمود كـهـ ضـريب آلفـاى كرونبـاخ بـراى يرسشنامه شادكامى آكسفورد 19٪ بود .همجنين پايـايى آزمـون

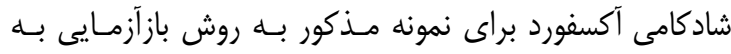

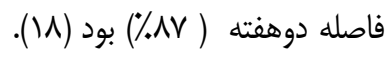
رضـايت اززنـدكى سـالمندان بـا برسشـنامه رضـايت از زنـدكى سالمندان(LSZ) سنجيده شد كه داراى سا كويه است. در نمـره دهى به سوالات به هر يك از سوالات مثبت كزينـه هـاى نمى

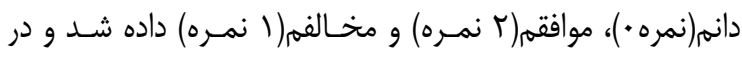
ارتباط با سوالات منفى گزينه هاى نمى دانم (نمـره () مخـالفم) نمره r) و موافقم(نمره •) در نظر كرفته شد. .در كل نمره رضايت از زندكى سالمندان بين صـفر و وَ اسـت و بــيهى اسـت كـه نمرات بـالاتر نشـان دهنــده رضـايت از زنـدَى بـالاترى اسـت.

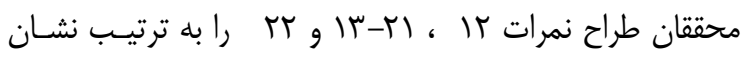
دهنده سطح رضايت كم، متوسط و زياد تلفى نموده اند. تقربس و

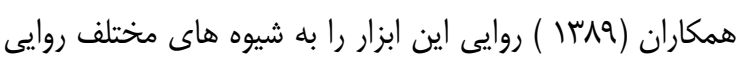
صورى، محتوايى و سازه مورد بررسى و تاييد قرار دادند. ضـريب يايايى ثرسشنامه به روش آلفاى كرونباخ با فرمسول Unequal محاسبه شدو ضريب آلفـاى كرونبـاخ Spearman Brown اين برسشنامه V9/ • بدست آمـــ و.ثبـات آن را بـهـ روش آزمـون مجدد از طريق ضزيب همبستخى خوشـه اى (سو/) مـورد تاييـد قرار داده اند(1). از روشهاى آمارى توصيفى جهـت تجزيـه و تحليل داده ها استفاده كرديــــ بعـلاوه از نـرمافـزار Spss16 و آزمون ضريب همبستخى ييرسون t مسـتقل و آنـاليز واريـانس جهت تجزيه و تحليل دادهها استفاده كرديد.
افراد اشـاره دارد و نمـره گَـذارى ان بـه شـيوه ليكـرت و امتيـاز سوالات از اتاع مى باشد. تقوى واميرى (ع) روايى ويايايى ايـن مقياس را در جامعه ايرانى مورد ارزيـابى قـرار دادنــــــه روايسى يرسش نامه ازسه طريق روايى همزمان،تحليل عاملى وهمبستخى هريك ماده ها با نمره كل سنجيده شد و مورد تاييد قرار كرفت و يايايى مقياس نيز از سه روش بازازمايى،تنصيفى وثبات درونسى

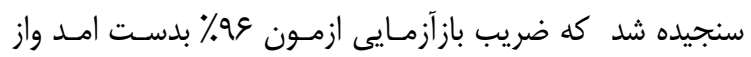
طريق روش تنصيفى يادونيمه كردن آزمون ،ضـريب همبسـتخى ييرسون براى كل مقياس M.M/بدست امد وهمجنين براى ثبـات درونى مقياس ،ضريب الفاى كرونباخ ا9٪بدسـت امـــ همجنـين ازآنجا كه روايى ويايايى برسشنامه در سالمندان ايرانى سـنجيده نشده بود محقق برآن شد تا روايى ويايايى آزمون را در سالمندان ايرانى نيز بسنجد. روايى صورى يرسش نامه را از طريق مشورت با هند تن از اساتيد روانشناس ومتخصص در اين زمينه تعيين شد سيس يرسشنامه بـين •r نفــر از سـالمندان بازنشسته در شهر اصفهان توزيع وتوسط آنها تكميل شد ويايايى ازمون نيزاز طريق محاسبه ضريب الفاى كرونباخ •^^٪ بدست آمد. شادكامى سالمندان با يرسشـنامه شـادكامى آكسـفورد سـنجيده شد. اين مقياس را آركايل' (1919) طراحى نمود كه شامل 9 (19 سو ال است. هر سؤال شامل جهار عبارت است كه از صفر تا ץ نمره كذارى مى شود؛ بنابراين نمر هٔ هر آزمودنى از صفر تـا لما در نوسان است. روايى و پايايى اين يرسشنامه در هـروهش هـاى مختلف مورد بررسى قرار ترفته است به عنـوان مثـال آركايـل و همكاران بايايى اين يرسش نامه را به روش آلفاى كرونبـاخ 9/9 و روايى همزمان آن را سع/ بدست آوردند (IV). قادرى (I) (I) نيز جهـت اطمينـان از روايسى و پايـايى آزمونها بـراى كَروه سالمندان،آزمون را براى نمونسه •ه نفـــى (ها مـرد و ها زن) از 
يافته ها

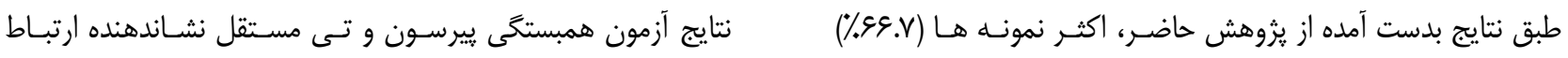

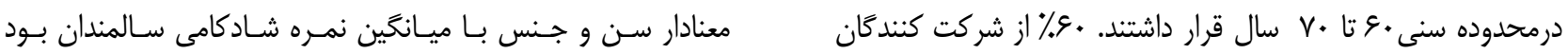

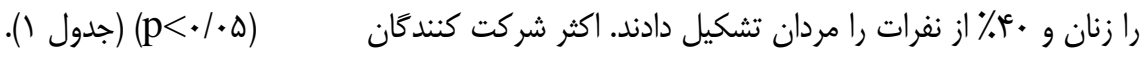

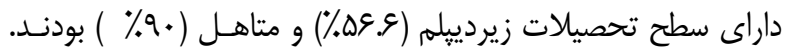

جدول () ارتباط ميانكين نمره تجربيات معنوى روزانه و شادكامى سالمندان با برخى مشخصات دموكر افيك

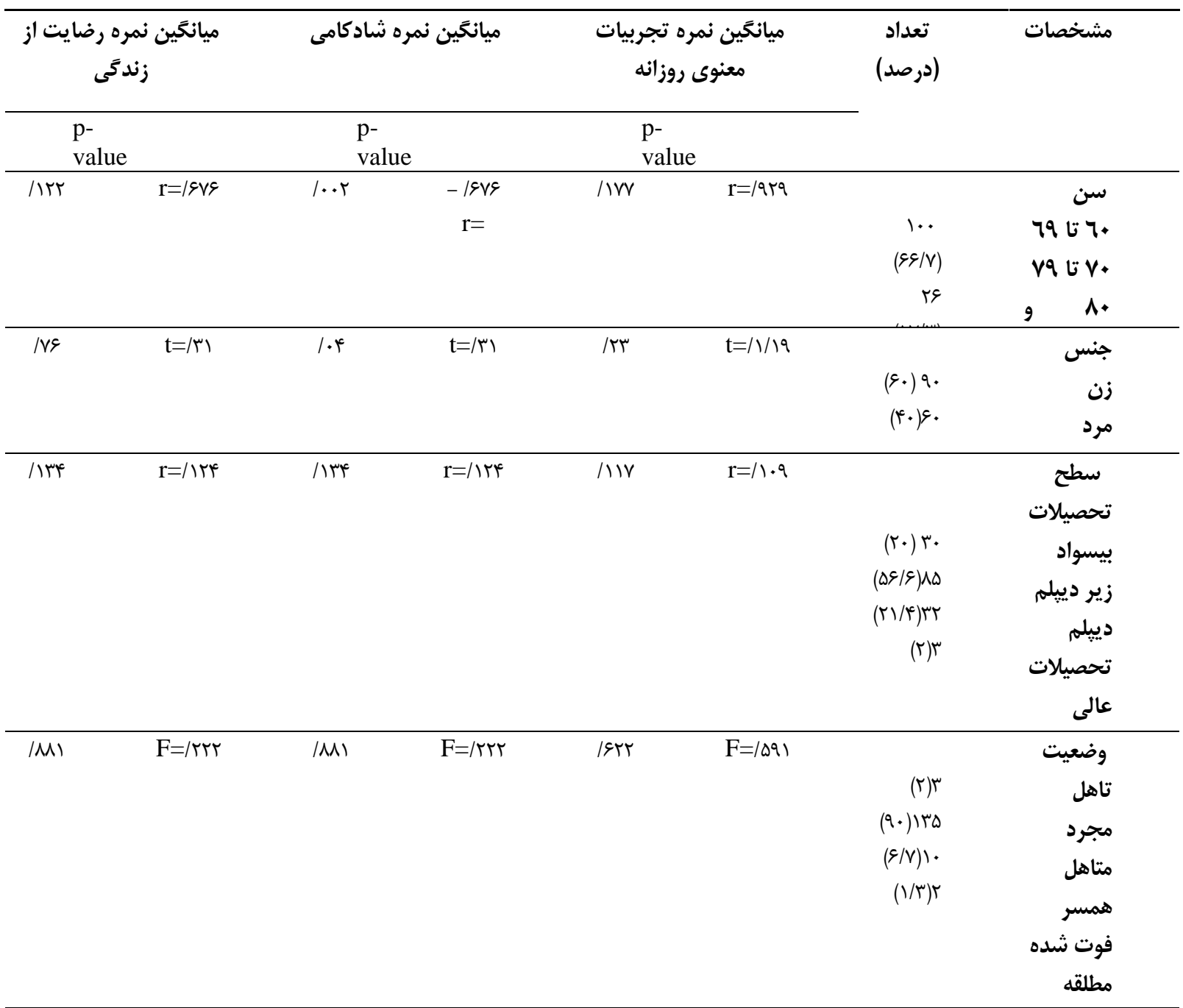

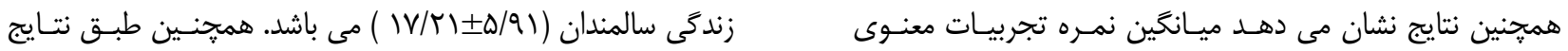

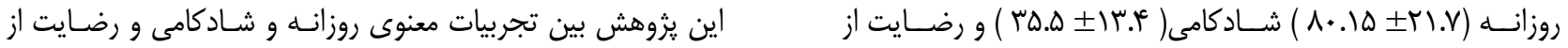




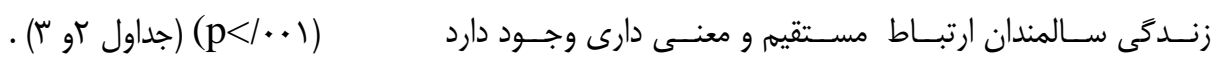

\begin{tabular}{|c|c|c|c|c|}
\hline همبستخى & ضريب & انحراف معيار & ميانكين & متغير \\
\hline $\mathbf{r}$ & $\mathbf{p}$ & & & \\
\hline \multirow[t]{2}{*}{ loFA } & $</ . \cdot 1$ & $r M / r$ & $\Lambda \cdot / 10$ & تجربيات معنوى روزانه \\
\hline & & $1 \pi / r^{c}$ & $r \Delta / \Delta$ & شادكامى \\
\hline
\end{tabular}

\begin{tabular}{|c|c|c|c|c|}
\hline همبستكى & ضريب & انحراف معيار & ميانَين & متغير \\
\hline $\mathrm{r}$ & $\mathrm{p}$ & & & \\
\hline \multirow[t]{2}{*}{ /FMe } & $1 \cdots 1$ & $18 / 9$ & $V \pi / l 1$ & تجربيات معنوى روزانه \\
\hline & & $r \cdot 10$ & $|V / T|$ & رضايت از زندَّى \\
\hline
\end{tabular}

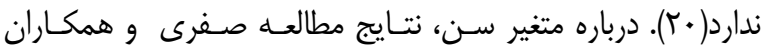
(IMMM) همسو با نتايج مطالعه حاضر نشان داد بين دو متغير سـن و شادكامى نمونه هاى مورد يزوهش رابطـــه معنــادارى وجـود دارد؛

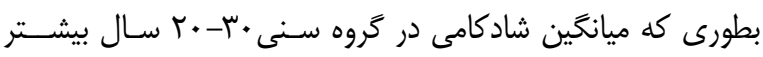
اسـت(آ) .طبق نتـايج مطالعـه حاضـر، تجـارب معنـوى روزانـه سالمندان در سطح بالا و ميزان شادكامى آنها كمتر از حـد متوسـط بود. بـا وجـود اسـتفاده محـدود يـروهش هـاى داخلـى از مقيـاس تجربيات معنوى روزانه براى سـنجش سـطح معنويـت سـالمندان، نتايج برخى مطالعات كه از مقياس سـلامت معنـوى يـا بهزيسـتى معنوى براى سنجش معنويت در سـالمندان اسـتفاده شــه، سـطح سلامت معنوى سالمندان را در حد متوسط و يا بالا ارزيابى كرده اند (T)(T/(T). درواقع مذهب و معنويت براى بسيارى از مردم كشورمان اهميت داشته و اين مساله براى سالخوردمًان مهمتر از جوانترها مى

\section{بحث و نتيجه كَيرى}

يزوهش حاضر به بررسى ارتباط تجارب معنوى روزانه با شادكامى و رضايت از زندگى سالمندان عضو كانون بازنشستىى كشورى شهر اصفهان برداخت. نتـايج بدسـت آمـده حـاكى از ارتبـاط معنى دار جنس و سن سالمندان با ميزان شادكامى آنها بود؛ به كَونسه اى كـهـ زنان سالمند نسبت به مردان شادكام تر بوده و نيز با افـزايش سـن سالمندان ميزان شادكامى آنها كاهش يافت. در همين ارتباط نتـايج مطالعه قادرى (9 (1) و با هدف تعيين ارتباط جهت كيرى مـذهبى و شادكامى سالمندان نشان داد كه ميانكين نمره شادكامى در زنـان بيشتر از مـردان سـالمند بـود(1). امـا نتـايج مطالعه مكبريـان و همكاران (سوسו) كه در يزوهش خود به مقايسه شـادكامى زنـان و مردان سالمند فعال و غير فعال شهر تهران برداخت، نشـان داد كـه بـين شـادكامى زنـان و مـردان ســالمند تفـاوت معنـادارى وجـود 
وجــود داشت (وَ). در تبيين اين يافته از مطالعه حاضر، مى توان بيان داشت عمل به باورهاى دينى موجب تقويت رابطأُ معنوى فرد بـا خـــا و ارتقـاء معنايابى در زندَّى فرد شده، اين موضـوع باعـث شادكامى بيشـتر شخص مى شود. كالدور نيز معتقد اسـت از آنجـا كـه افراد مذهبى نزديكترين دوستان خود را از ميان افراد مـذهبى انتخـاب مى كنند، علاوه بر داشتن احسـاس نزديكسى بـهـ خداونــ، نسبت به مردم ديد مثبتى دارند و همه اين عوامـل بـــر شـــادمانى آنها مس افزايد. نتايج هـروهش حاضـر نشـاندهنده ارتبـاط معنـادار ميـانگين نمـره تجربيات معنوى روزانه سالمندان با ميزان رضـايت از زنـدكى آنهـا بود. در همين ارتباط مطالـهـ حاضـر كوليشـاو و همكـاران(با •r ) گززارش كردند معنويت بـا رضـايت از زنـــى در سـالمندان ارتبـاط

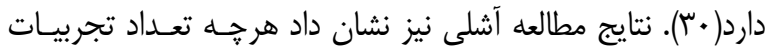

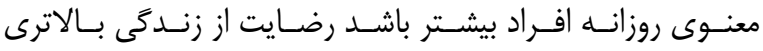
برخوردارند (اس). ن نتايج مطالعه يعقوبى،حققى و منظمى تبـار نيـز نشان داد كه بهزيستى معنوى و اميدوارى، از عوامل مهم رضايت از

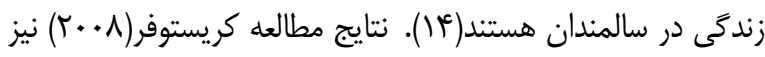
نشان داد تجارب معنوى روزانه با ابعـاد مختلـف بهزيستى روانى( شادكامى، رضايت از زندگى و اميدوارى نسبت به آينده ) سـالمندان مرتبط است (ץ؟). درتبيين اين نتيجه از مطالعه حاضر مى توان بـهـ اين موضوع اشاره كرد كه احساسات خاصى كـه از طريـق تجـارب

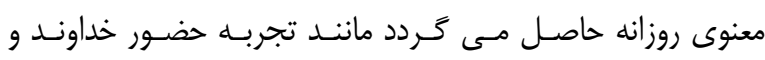
راهنمايى و هدايت از طرف خداوند مى تواند اسـترس هـاى روانى فرد را كم كند و از طريـق كمى كـردن ايـن اسـترس هـاى روانى سلامت روانى افراد ارتقا مى يابد علاوه براين تجربه آسايش، عشق و دوست داشتن و آرامش معنـوى كـه از طريـق تجـارب معنـوى روزانه ايجاد مى گَردد مى تواند به كَونه اى احساسـات منفى فـرد
باشد(ץ). از نظر وضعيت شادكامى نتايج مطالعـه قـادرى (M IM ) (Tه) و جمال زاده و كلزارى (זوجسا) (ع) همسو بـا نتـايج مطالعـه حاضر در مطالعات خود ميزان شادكامى سالمندان را إيين كَزارش نمودند. در توضيح نتايج به دست آمده مى توان كفت كه تجربيـات

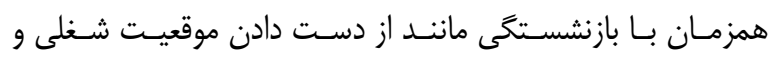
اجتماعى و دوستان و آشنايان منجر به كَوشـه نشـينى اجتماعى و كاهش ميزان شادكامى سالمندان بازنشسته مى كردد. ديخـر نتـايج اين يـروهش حـاكى از سـطح متوسـط ميـزان رضـايت از زنـدكى سالمندان بود. در همين ارتباط نتــايج مطالعـهـ سـليمى و همكـاران

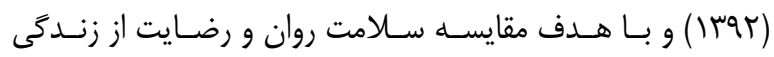
سالمندان بازنشسته دو دانشـكاه علــوم يزشـكى جنــى شـايور و شهيد جمران اهواز به اين نتيجه دست يافت كه اكثـر واحســدهاى مــورد ״ــروهش از سطح رضـايت از زندكى متوســـى برخوردار

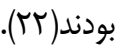
همجنين يافته هاى بزوهش حاضر نشان مى دهـــ بـين تجربيـات معنوى روزانه و شادكامى سالمندان بازنشسته ارتباط معنادارى وجود دارد؛ به عبارتى ديخر، تجربيات معنوى روزانه سالمندان كه شـامل تجربه شخصى، درونى وذهنى فـرد از دنيـاى وراى دنيـاى مـادى است با شادكامى در سالمندان مرتبط مى باشـــ. در همـين ارتبـاط رولد' (1) با نيز در يثوهش خود بر ارتباط معنادار سلامت معنوى و شادكامى تاكيد نمود(TV). منظرى، توكلى و عراقى :ـور (1) • (T) نيز بين دين دارى و شادكامى ارتباط مثبت و معنادارى يافتند (؟)).

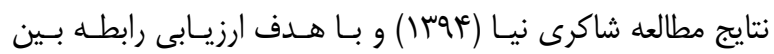
فعاليت هاى بدنى، عمل بـهـ باورهـاى دينسى و شـادكامى در زنـان سالمند به اين نتيجه دست يافت كه بين عمل به باورهاى دينس و

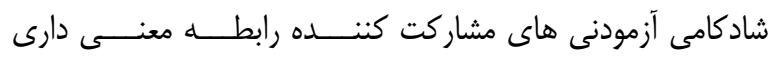


جمله محدوديت هاى يثوهش حاضر كـهـ سـبب مـى شـود تعمـيم يذّيرى يافته هاى اين مطالعه راتحت تاثير قـرار دهــ، كوجـى بودن جامعه آمارى و انجام مطالعه در يـك شـهرو مركـز بـود لــذا ييشنهلاد مى گردد يزوهش هاى آتـى ضـمن در نظـر گَرفتن ايسن محدوديت ها، مداخلاتى با تاكيد بـر بعـد معنـوى و سـلامت روان

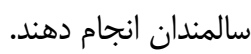

\section{تقدير و تشكر}

اين مقاله حاصل طرح تحقيقاتى به شماره ع.بسوץ است كـه در معاونت يزوهشى دانشگاه علوم يزشكى و خدمات بهداشتى درمانى اصفهان به ثبت رسيده است بدينوسيله لازم مى دانم از همكـارى مسئولين واعضاى محترم كانون بازنشستعان كشورى اصـفهان و كليه سالمندانى كه در به ثمر رسيدن اين يزوهش نهايت همكارى را داشتند، سياسگزارى نماييم.
مانند افسردگى و استرس را از بين ببرد و باعث افزايش عزت نفس، ديدكاه مثبت و خوش بينى گردد(سّ) و درواقع يكى ارتباط قـوى بـاــا متافيزيك و ماورا مى تواندفرد را از هرگونه اضـطراب و اسـترس و احساسات منفى دور كرده و به زندكَى او معنا و مفهوم تازه ببخشـــ و اين احساس را در فرد يايدار كند كه برقدرت بى پايانى تكيه دارد

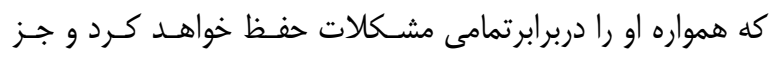
خوبى براى او نخواهد خواست (ع (Y) و به عبارتى معنويت ميتوانـد هيجانات منفى از جمله افسردگى واضطراب وخشم را كاهش دهـد. و درمقابل منجر به تقويت هيجانات مثبـت مانتـد اميدوارى،عشـق ورزى واعتماد به نفس شادمانى شود كه اين هيجانات مثبت نتايج مثبتى همجون افـزايش رضـايت از زنــدى را بــه همـراه دارد[12] درواقع معنويت ميتواند فاصـله بـين آنجـهـ كـه انسـان دارد وآنجــهـ ميخواهد داشته باشد را ير كند. و او را دردستيابى به موقعيتى جديد و افزايش رضايت از زندكى با كاهش فاصله بين واقعيت وايـده آل

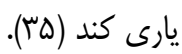
ازيافته هاى مطالعه حاضر جنين بر مى آيــد كـهـ هرجـهـ سـالمندان بازنشسته از تجربه معنوى روزانه بيشترى برخوردار باشند شادكامتر بوده و رضايت از زندگى بيشترى دارند.. بنابراين تجربيـات معنـوى مى تواند بعنوان يك منبع حمايتى مهم به سالمندان براى رضـايت از زندگى و شادكامى بيشتر كمك نمايد ـ بنابراين توجه بـهـ ايـن موضوع در برنامه هاى آموزشى بهلداشت حائز اهميـت اسـت. لـذا ييشنهلاد مى شوديرستاران نـاه جامع ترى نسـبت بـهـ نيـاز معنـوى سالمندان داشته باشند و بتوانند در سايه حفظ كرامت هاى انسانى و اخلاقى، خدمات و مراقبت هاى كامل تر و مناسـب تـرى را بـهـ آنان ارايه دهند .همجنين در نظر گرفتن برنامه ها و رويكردهـايى در جهت ارتقاى سطح تجارب معنوى سالمندان به منظور افـزيش رضايت از زندكى و شادكامى آنها ضـرورى بــه نظـر مـى رسـد. از 


\section{- References}

1) Jadidi A, Farahaninia M, Ganmohamadi S, Haghavi H. The Relationship between Spiritual Well-Being and Quality of Life among Elderly People Residing in Kahrizak Senior House .Iran journal of Nursing. 2014; 24(72): 46-58

2) Golparvar M,Bozorgmehri KH, Kazemi .Evaluation of the elements of retirement syndrome and its association with general health symptoms in elderly retired. Journal of Aging in Iran 2011;6(20):33-43

3) Mirzaei M, Shams-Ghahfarkhi M. Demographic characteristics of the elderly population in Iran according to the census 1976- 2006. Iranian Journal of Ageing. 2007; 2 (5): 1-10.

4) Mortazavi S, Ardabil R. Evaluation of the Elderly Mental Health of Sharekord and its relationship with demographic and social factor. Payesh journal. 2010; 10:485-492

5) Golparvar M,Bozorgmehri KH, Kazemi .Evaluation of the elements of retirement syndrome and its association with general health symptoms in elderly retired. Iranian Journal of Ageing. 2011;6(20):33-43.

6) Shukla P, Kiran U. Subjective Happiness among the Elderly across Various Groups. Journal of Humanities and Social Science. 2013; 13(6): 46-49

7) Rgayl, M. The psychology of happiness. 5th ed. (Translation by Calantari M etal.). Isfahan, Isfahan University Jihad Publication. 2004

8) Kajbaf MB, Sajadian P, Kaviani M, Anvari H. The Relationship between Islamic life-style with happiness and life satisfaction of students in Isfahan.Ravanshenasi-va Din 2012;4(4): 6174

9) Bagheri M, Sohrabi M, Ebrahimi M, Heidari-Fard J, Yanj J, Golchinmehr S. The Relationship between Life Satisfaction with Social Support and Self-efficacy in Communitydwelling Elderly in Sari, Iran. J Mazand Univ Med Sci . 2013; 23(101): 38-47

10) Mimandi M, Barghamandi M.The relationship between the practice of religious beliefs and life satisfaction among the elderly, Iran j Aging. 2010; 5: 87-98

11) Fatahi R.The effects of islamic spiritual group therapy on symptoms of dysthymic and quality of life of girl students of Isfahan university [dissertation].(Isfahan): Isfahan university .2009: 200

12) Bolhari G, Zamanian S, Naziri GH. The effectiveness of group therapy and spiritual approach to treatment of depression, anxiety and stress in women with breast cancer. Journal of Women Sociology. 2011; 3(1): 85-90 
13) Adler MG, Fagley N S. Appreciation: Individual differences in finding value and meaning as a unique predictor of subjective well-being. Journal of personality.2005; 73(1):79-114.

14) Yaghoobi A, Mohagheghi H, Monazami tabar F. The relationship between spiritual wellbeing and hope with life satisfaction in elderly. Ravanshenasi-va Din. 2014; 7(3): 109-121

15) Underwood G, Teresi J. The Daily Spiritual Experience Scale: Development, Theoretical Description, Reliability,Exploratory Factor Analysis, and Preliminary Construct Validity Using Health-Related Data. The Society of Behavioral Medicine. 2002;24(1): 22-33

16) - Taghavi M, Amiri H. Assess the psychometric properties of the questionnaire daily spiritual experiences. Biquarterly Journal of Isalmic Education. 2010; 5(10): 151-162.

17) Argyl M, Martin M, Grossland J. Happiness as a function of personality in: JP Forgas and JM Innes (eds). Recent advances in social psychology: An international perspective (pp.189203). North Holland: Elsevier Science Publisher; 1989.

18) GHaderi D. The relationship between religious orientation and happiness of the elderly. Iranian Journal of Ageing. 2011; 5(18): 61-71.

19) Tagharobi Z, Tagharobi L, Sharifi KH, Sooki Z. Reliability and validity of life satisfaction questionnaire in Iranian elderly.2010;10(1): 5-13

20) Mokaberian M, Kashani V, Kashani K, Namdar Tajari S, The Comparison of Happiness in Active and Inactive Old Men and Women in Tehran, Development \& Motor Learning. 2014; 6(2):183-194.

21) Safari Sh, Happiness and Its Relationship with University Students' Demographic Factors, Industrial and organizational psychology, 2011; 1(2):79-87.

22) Salimi E, Dashtbozorgi B, Mozafari M, Tabesh H. Investigating mental health status and life satisfaction of retired elderly referred to retirement's centers of the Jundishapur University of medical sciences and shahid Chamran University in Ahvaz. . Journal of Geriatric Nursing. 2013: 1(1): 21-31

23) Shahsavarloo Z, Lotfi MS, Taghadosi M, Mousavi MS, Yousefi Z, Amirkhosravi N. Relationship between components of Spiritual well-being with hope and life satisfaction among elderly with cancer in Kashan. . Journal of Geriatric Nursing. 2013;1(2) : 44-53

24) Rezaei M, Seyedfatemi N, Hosseini F. Spiritual Well-being in Cancer Patients who Undergo Chemotherapy]. HAYAT. 2008; 14(3-4): 104.

25) Ghaderi D. The Survey of Relationship between Religious Orientation and Happiness among the Elderly Man and Woman in Tehran. Salmand. 2011; 5 (4):64-71. 
26) Gamalzadeh R, Golzari M.The effectiveness of hope therapy on increasing happiness and life satisfaction of elderly Resident in Borujen city nursing home. Quarterly of woman and society.2014; 5(2):31-40.

27) Rowold J. Effects of Spiritual Well-Being on Subsequent Happiness, Psychological Well-Being, and Stress. Journal of Religion and Health .2011; 50:950-963.

28) Manzari-Tavakoli A, Eraqipoor N. The relationship between religiosity and happiness among female students of Islamic Azad University of Erman. Quarterly Educational Psychology. 2011; (6): 19-45.

29) shakerinia I, Ramazani F. The relationship between physical exercise, religious beliefs and happiness in older women. jgn. 2016; 2 (2):25-36.

30) Cowlishaw S, Niele S, Teshuva k, Browning C and Kendig H. Older adults' spirituality and life satisfaction: a longitudinal test of social support and sense of coherence as mediating mechanisms. Ageing \& Society journal. 2013; 10(17):1243-1262.

31) Ashley N. Daily experience of spirituality and satisfaction with life in African americans, ProQuest Information and Learning Company. UMI: 3552671. 2011: 80-90.

32) Christopher G,Ellison,Daisy Fan. Daily Spiritual Experiences and Psychological Well-being among US Adults, Springer Science, Soc Indic Res .2008; 88:247-271.

33) Underwood G, Teresi J. The Daily Spiritual Experience Scale: Development, Theoretical Description, Reliability,Exploratory Factor Analysis, and Preliminary Construct Validity Using Health-Related Data. The Society of Behavioral Medicine. 2002; 24(1): 22-33.

34) Shahsavarloo Z, Lotfi MS, Taghadosi M, Mousavi MS, Yousefi Z, Amirkhosravi N. Relationship between components of Spiritual well-being with hope and life satisfaction among elderly with cancer in Kashan. . Journal of Geriatric Nursing. 2013; 1(2): 44-53.

35) Fallah R, Golzari M, Dastani M, Akbari ME. Integrating Spirituality into a Group Psychotherapy Program for Women Surviving from Breast Cancer, Iran J Cancer Prev. 2012; 3:141-147. 